\title{
Politics, Ideology and Landscape: Early Christian TIGRANAKERT IN ARTSAKH
}

\author{
Hamlet Petrosyan
}

Erevan State University

\begin{abstract}
Tigranakert in Artsakh was founded at the end of $90 \mathrm{~s} \mathrm{BC}$ by the Armenian King Tigranes II the Great (95-55 BC) and in the Early Christian period continued to play a role of an important military-administrative and religious center. As a result of excavations the Early Christian square of the Central district with two churches, remains of a monumental stela with a cross, as well as an Early Christian underground reliquary and a graveyard were unearthed.

The sepulchre-reliquary was opened under the floor of the small church of early Christian Square. It has only the eastern entrance. As had been shown by further excavations Saint Grigoris's sepulchre-reliquary in Amaras also had an eastern entrance. Saint Stephanos's reliquary in Vachar also has only an eastern entrance. All these three structures are dated from 5th-6th centuries. In early Christian East the only tomb that had an only eastern entrance is Holy Sepulchre in Jerusalem.

Analysis of the data on Vachagan the Pious (end of 5th-early 6th centuries), king of Albania (which included since the middle of 5th century the eastern provinces of Greater Armenia Artsakh and Utik), allows us to conclude that at the end of the 5th century the king initiated the ecclesiastical reform, trying to link the origin of the Albanian church to Jerusalem. One of the manifestations of this reform was the creation of the legend of the Apostle Yeghisha arriving to Albania from Jerusalem. Comparative analysis of archaeological, architectural and written data leads to the conclusion that all three tombs with the single east entrance are the result of the reformist activity of Vachagan, and the idea of single eastern entrance, most likely, was taken from the tomb of the Holy Sepulchre in Jerusalem.

A new approach to the localizations of Early Christian sanctuaries in and near Tigranakert allows to compare this sacred area with early Christian sacred topography of Jerusalem.
\end{abstract}

Keywords: Armenian art, Artsakh, Early Christianity, Eraly Christian Archaeology. 


\section{Introduction}

The Late Hellenistic ${ }^{1}$ city of Tigranakert is located in the Askeran region of Artsakh (Nagorno Karabagh). The city is located in the lower valley of Khachenaget river, the second largest river in the highland. It is spread over the south-eastern slopes of Mount Vankasar and is adjacent to the slopes near the Royal Springs (Shahbulagh) occupying a territory of more than 70 hectares. The city of Tigranakert was discovered in 2005 and until now archeological excavations are being conducted by the Artsakh expedition of the Institute of Archeology and Ethnography of the National Academy of Sciences of the Republic of Armenia. ${ }^{2}$

Tigranakert in Artsakh is one of numerous settlements carrying the name of Tigran, however it's the only settlement that has a precisely identified location. Based on the rich archeological data, the archeological museum of the city was created in 2010. Tigranakert is one of the most visited, well-known archeological monuments in Artsakh that has a proper presense on the internet.

During the 14 years of excavations the following sections of city were uncovered (Fig. 1):

a. Fortified district ( 1 st century BC) with Citadel, the $83 \mathrm{~m}$ long fece-wall separating the citadel from the district, rock foundations of about $450 \mathrm{~m}$ to the southern wall of the same district, up to $5 \mathrm{~m}$ high and $320 \mathrm{~m}$ long stretched part of the northern wall with rectangular and circular towers (Fig. 2, 3, 4),

b. first and second Late Hellenistic districts, and an Early Christian cemetery that covered partly the first district (Fig. 5),

c. the Late Hellenistic cemetery with jar and cist burials (Fig. 6),

d. Early Christian rock carved complex and a rocky canal near the city $(\mathbf{F i g} . \mathbf{7 , 8})$,

e. the Early Christian Square in the Central District with remnants of two churches, a memorial stele, an Early Christian underground reliquary-sepulchre and a graveyard (Fig. 9),

f. a pool near the royal springs, the remnants of postal station built in 19th century.

As a result of archaeological research, it is possible to talk about a large residential settlement with advanced urban planning and construction technics, that was founded in the 1 st century $\mathrm{BC}$ and has survived until the end of 13 th century.

Ancient Tigranakert has been constructed in accordance with the advanced Hellenistic urban planning principles and masonry technics: triangle model of planning of the fortified district by using zigzag walls, strong alternation of rectangular and round

1 In the case of Tigranakert, under the term Late Hellenistic we mean the historical period from $1 \mathrm{st}$ century BC to $3 \mathrm{rd}-4$ th centuries AD.

2 The works of the expedition are directed by Hamlet Petrosyan (Institute of Archaeology and Ethnography of NAS, RA, Yerevan State University). The permanent members of the expedition are Lyuba Kirakosyan (National University of Architecture and Construction of Armenia), Vardges Safaryan (Artsakh State University), Inesa Karapetyan (Institute of Archaeology and Ethnography, NAS, RA), Tatyana Vardanesova (Yerevan State University), Armine Gabrielyan, Nzhdeh Eranyan, Ruben Hovsepyan (Institute of Archaeology and Ethnography, NAS, RA). Also Zhores Khachatryan, Ashot Piliposyan, Hayk Hakobyan, Aghavni Zhamkochyan, Ruben Vardanyan, Roman Hovsepyan, Nora Engibaryan, Hasmik Margaryan, Lilit Minasyan, Giusto Traina, Franceska Cheli, Sarah Champi, Paul Bailey took part in works in different years. 
towers, foundation of fortifications exclusively on rocky base, quadras with rustication, buvels, with "swallow-tail" connections, and usage of limestone cement. All structures were made with local white limestone, which gave the city a white appearance, making it visible from afar.

Among the uncovered artifacts perfect examples of colored, black and gray Hellenistic pottery, seals and gemms, a clay disk with Armenian inscriptions, early medieval glass and the 9th-13th centuries glazed ceramics can be singled out. In Hellenistic cemetery among various findings (iron rings, golden beads, fragments of weapons, ceramic vessels etc.) silver drachmas of Parthian kings Mithridates the Third and Vologes the Second (half of the 1st century BC) were found.

The Greek geographer Strabo (1st $\mathrm{BC}-1 \mathrm{st} \mathrm{AD})$ most likely was aware about the Tigranakert of Artsakh and has mentioned a Tigranokerta, near Iberia (i.e. Georgia) (Strabo, 11, 14, 15). ${ }^{3}$

\section{Tigranakert in the Written Sources of Early Middle Ages}

There is not a lot of information about Artsakh's Tigranakert in Armenian sources, but it is worth noting that the majority of them refer to the early Christian era. Written sources seem to emphasize the essential military and administrative and religious role of Tigranakert. The first mention of Artsakh's Tigranakert is found in the 7th century Armenian historian Sebeos. ${ }^{4}$ Describing the Persian invasions of the Emperor of Byzantium Heraclius in 622-624, the historian writes that in one of the episodes of that war, the Byzantine emperor trying to escape from the persecuting Persians, crossed from Atrpatakan to Albania (in this case Artsakh and Utik, which approximately from 5th century were adjusted to Caucasian Albania by Sasanids), but a Persian army coming from the Gardman side crossed his way in "the other Tigranakert." The Emperor tries to get back, but this time another Persian military unit is coming out against the "Tigranakert avan." The Byzantine army defeats this last faction and travels through Tsghuk to Nakhchavan.

The most direct conclusion from Sebeos' testimony is that in the early 7th century there had been two settlements called Tigranakert in Artsakh and Utik', from which "the other Tigranakert" was located in the north and the "Tigranakert awan" in the south. More than likely, the author calls "the other Tigranakert" in order to distinguish it from the awan Tigranakert. If we take into consideration that the Emperor's army would have to go through a busy road to get to Georgia as soon as possible, it was more likely that avan Tigranakert had been founded not far or even directly near the road located on the edge of the Artsakh Mountains and the Utik' Plain. ${ }^{6}$

3 Traina 2015, 44.

4 Sebēos 1979, 125.

5 As for the term "avan," it is used by Sebeos as a fortified settlement, which may in some cases be encircled and enclosed around the castle (Petrosyan 1988, 116-121).

6 Based on the description of Sebeos, S. Eremyan $(1952,2)$ placed one of the cities called Tigranakert on his map to south of Partav, and the other one in the north, near Gandzak (present-day Ganja, in the Republic of Azerbaijan). 
In the letter of Armenian catholicos Eghia decribing the consul of Partav in the early 8th century ${ }^{7}$ and including also in the History of Movses Daskhurantsi (or Kaghankatvatsi), ${ }^{8}$ there is information that the priest David of Kaghankatuyq and the priest Petros of Tkrakert (in some manuscripts, just Tigranakert) participated in the meeting as well. First, we can assume that Tkrakert is a local pronunciation of Tigranakert, secondly, it is likely that avan Tigranakert or Tigranakert was not too far from Kaghankatuyq (as it is mentioned immediately after). The fact that Tigranakert was an important settlement and religious center at this time is also confirmed by the fact that at the end of the 7 th century at the top of the Mount Vankasar, a cross central dome was built, which was a famous sanctuary untill the end of the 18th century. In the north-eastern part of Vankasar, one of the oldest Christian centers of Artsakh, a cave-worship complex is located. The complex consists of a rocky road, cave-carved church, a narthex, all of these structure are decorated with numerous cross-compositions, Greek and Armenian inscriptions. ${ }^{9}$ Traces of Early Christian churches and monuments have been identified and partly excavated. Mountain Tsitssar is located in the south-west of the city.

As we will see below, the excavations at the Central District of Tigranakert have revealed the remnants of a tremendous size city church dating back to the 5th-6th centuries. It is more likely that Petros was the priest of this church. Let us mention also the Sasanian seals found during excavations (4th-6th centuries), which are important data indicating the city's administrative-commercial activity in the Early Middle Ages. Facts thus prove that Tigranakert was a major military-administrative and religious center located in the early Christian era in the neighborhood of Partav, the capital of the country.

\section{Tigranakert's Early Christian Square (Fig. 10). The Large Church (Fig. 11)}

Starting with the first steps of the archeological research, parallel to the excavations of the Hellenistic districts the expedition paid special attention to the medieval remnants of the city. The study of the site in 2005 has already revealed that the material traces of the medieval culture are richly visible from the late medieval castle to the south-eastern stretch of about seven hectares, with a 4-6 meters high enclosure surrounding it. It was evident that we deal with artificial heights caused by centuries of cultural activity. Conventionally we called the name of that part of the city the Central district (because it has an intermediate position compared to the Fortified district, the Early Christian Cemetery, the Hellenistic districts, and the late medieval castle, we can say that it is surrounded by them), all of which are noticeable throughout the area, with fragments of walls, tonirs, pits, plain and glazed pottery.

In the central part of the district excavations a large pit strethced from west to the east and large masses of stone walls were visible before excavations. Taking into account the fact that Makar Barkhudaryants in his descriptions of the area of Tigranakert in the late

7 Hakobyan 1981, 150.

8 Kałankatuac'i 1983, 300.

9 Petrosyan, Kirakosyan 2016, 165-170. 
19th century, speaks of the ruins of a vast church in the territory of Tigranakert, ${ }^{10}$ we assumed that the pit spreading from west to east could be the remnant of the church.

In 2006 a part of the pit, which could roughly correspond to the structure of the apse and the eastern part of the prayer hall (this part of churches as a rule has been better preserved), was separated (a square of 5 meters of the side) and excavations commenced. Only a few hours later, the first abbey stone of the church's apse and the southern wall were opened at a depth of about $0.5 \mathrm{~m}$. As a result of the excavations in 2006-2009, the ruins of a large early Christian temple were uncovered at a depth of about 3.5 meters.

The church by its composition, belongs to the same type of basilica dating back to the 4th-6th centuries Armenia and Caucasus. By its architectural composition and decoration it is the earliest, most extensive and beautifully decorated hall of its size in the Eastern Caucasus. The excavations of the temple and the facts validated during the excavations give an almost complete understanding of the scale of initial structure desing and consicutive change.

Originally, it was a single nave basilica type church with outer five-faceted apse. Later, the five-dimensional volume was incorporated into the rectangular volume, and the southern sacristy was added, which had an entrance from the outside. The excavations in sacristy area uncovered a water line made of ceramic pipes and tiles. This is a sufficient basis to assume that the southern sacristy was built as a baptistery, and the water supply provided the baptismal drainage. Apparently, after the construction of the baptistery, the southern open air peristyle was added.

As a result of these changes and additions, the inner appearance of the church has remained the same. In addition to the semi-circle in the east, the rectangular regular hall, which has a well-rounded rectangle, also has a $2.5 \mathrm{~m}$ wide choir part, which is higher than $0.5 \mathrm{~m}$. It's completely flattened. From there to the prayer hall goes down two stairs. The excavations of this part of the church also uncovered thin stone pillars that separated the choir from the prayer hall.

In the early churches, the main altar is usually one degree higher than the floor of prayer hall and divided into a bema and a choir. It should be noted that although the existence of the choir in the early churches is predictable, archaeologically it is the first fixation as real architectural structure.

The church was built on a three-staired basement with large polished limestone blocks in inner and outer rows and with lime mortar and little stones in mid part. It had a western, southern and northern entrances, cornice with crackers and wooden roof covered by ceramic tiles. The enterences had a pair of columns, completed with ornamented capitals. During the excavations, numerous examples of cornices, columns, hundreds of fragments of tiles and two capitals were found. The carving compositions on the capitals represent in one case a cross in the luminaries, and in the second case a cross in the garden environment (Fig. 12), both are well-known early Christianity themes. Especially noteworthy is the grape vines (the branches, leaves, carnations, cloves) on the second capital, which are typical of the earliest examples of these compositions.

According to preliminary data, the church was destroyed and burned in the 8th-9th centuries, and new dwelling complexes were built on its ruins. Only a century later, the

10 Barxudareanc' 1895, 20. 
adjacent part of the southern peristyle again receives a christian worshipping function and a khachkar (cross stone) is erected and burials were uncovered to the north and west.

The existence of such a large Christian church is an important argument in favor of the fact that Tigranakert preserved its status as an important settlement in the early medieval times and that the testimonies of the early medieval Armenian sources are accordance with the archeological results of Tigranakert.

\section{Northern Courtyard and the Small Church (Fig. 13)}

From architectural features mentioned above we want to stress the two northern entrances. If the presence of the western entrance was quite natural, and the presence of the southern pair of entrances was natural, considering the size of the church and the presence of the peristyle and baptistery adjacent to the south, the presence of the northern pair of entrances was extraordinary. Early Christian temples typically do not have entrance from the north, but in some individual cases, due to lansdcape restrictions where it was impossible to open a western or southern entrance, a northern entrance was created. However this is not the case here, since the church is located on a flat plain with access from all four sides. This circumstance was the basis for the assumption that there was an important structure (or structures) in the yard adjacent to the church, which is why a pair of northern entrances were created. So after the church and the immidiate vicinity of the southern courtyard, we decided to continue excavating the northern part. The expectations were fully justified as the excavations revealed a large paved courtyard, with fragments of an Early Christian memorial stella. The stella had a basement, pedestal, column, capital and a winged cross. A small church and reliquary-sepulchre was uncovered under the eastern altar of the church (Fig. 13) and a graveyard adjusent to the western part of this church. An archaeological study of this sepulchre (Fig. 14, 15, 16) served as a basis to consider similar Artsakh structures and reforms of Vachagan the Pious.

Though from the church only some blocks of first row and foundations have been preserved, its layout, dimensional solutions and construction are completely understandable and apparent. It had a rectangular layout with circular altar with five-faseted outer appearance, western and southern entrances (the interior of the prayer hall is $9.8 \times 4.5$ meters, the outer dimensions are $16.3 \times 8.3$ meters). The floor was covered with limestone slabs.

The yard between two churches is about 5 meters wide and is covered with rough, irregular slabs. Only the path to the southern entrance of the small church is made up of larger stones, among which an anthropomorphic stela dating to the 8-7 th cc. first millennium $\mathrm{BC}$ was used.

\section{The Sepulchre (Fig. 14, 15, 16)}

During the excavations in 2013, a rectangular area surrounded by four large stone blocks was uncovered on the eastern end of the newly-opened small church, where the cultural 
layer was deep into the natural ground. At the depth of $1.40 \mathrm{~m}$ from the level of the yard, as a result of the excavation of the well $(1.95 \times 1.50 \mathrm{~m})$, three polished stairs and the eastern entrance were unearthed (Fig. 16).

The excavations of 2014 uncovered the southern and northern walls of a building to the west, with polished limestone blocks, separate parts of the vaulted ceiling, that were also made with polished blocks. In the northern and southern walls niches were embedded. The southern part of the altar wall which goes in parallel with the new stricture was implemented with rough, large blocks, which made it possible to assert that the structure was included in a protective coating for softening the lateral pressure from the side of church's wall. Excavations in the southern part of the building have also revealed a part of the roof covered with a lime plasterboard. The upper upstream point slightly raised from the floor surface of the church and was included in the volume of the altar. Obviously, we deal with a structure built with the church and enclosed under the church's altar.

When digging went deeper than 2.8 meters below the ground floor and the cultural layer continued, it was decided to stop the excavations due to the threat of collapse. The excavations were stopped in this area and the area was filled until the ground level. The building was destroyed in 8th-9th centuies during the collapse of the Early Christian Square, but the ruins of the building were a subject of curiosity and treasure hunts for centuries, as a result of this the original floor was not preserved. So, the question of burial is still pending. We named this construction conditionally sepulchre-reliquary, ${ }^{11}$ based on the small niches in the walls.

As the excavations have shown, the whole structure is made of large polished lime blocks, has a clear west-east orientation with accordance of the orientation of the church, a cylindrical ceilling, and which was strange-a single eastern entrance. The niches in the southern and northern walls have cuboid volume with arch shape ends at the east, most probably intended for the saints' relics.

Despite the devastation, most of the reliquary's stones have been preserved and its further restoration will not cause any problems. It can be asserted that this is the third well-preserved structure in the Early Christian culture after the Aghtsk royal mausoleum and the Saint Grigoris Mausoleum in Amaras. Both of these structures also contained bones but not burials. The excavation results make it possible to validate a new composition of this type of structure, the main feature of which is the only eastern entrance.

After the excavations in 2014, it is possible to restore the process of formation of the Early Christian Square of Tigranakert (Fig. 10):
a. building a sepulchre,
b. construction of a small church with the sepulchre under the altar,
c. construction of a large urban church south of the small church,
d. a southern paved courtyard and a stell,
e. the graveyard in the western yard of the small church.

In the Tigranakert sepulchre, the only eastern entrance is exceptionally extraordinary for the Early Christian sepulchres and for the wider, generally the religious structures. The theological and ritual direction of Christianity from the west to the east, from where

11 Hereinafter until the final conclusion we will name "sepulchre" this type of constructions of Artsakh. 
the Christ's Second Coming is expected, conditioned both the ritual movement of the believer from west to east, and the orientation of the sacred area, including the sacred structures from west to east (west-east orientation and stretching, west main entrance, location the altar in the east, etc.). Even in our sepulchre, which has the only eastern entrance, the "movement" to the east is documented by the structure of niches whose eastern parts have been given a rounded solution.

\section{Parallels to the Sepulchre in Tigranakert}

The problem of clarifying this peculiarity of Tigranakert's sepulchre was the reason for initiating excavations in the most prestigious early Christian sepulchre of Artsakhthe Saint Grigoris sepulchre of Amaras, the main volume of which is located under the eastern altar of the present church built in 1858. This sepulchre had two southern and northern entrances, had a long corridor instead of an altar and based on the look of it had been cut during the construction of the church and the continuation of this corridor should be outside the church behind the eastern wall. The excavations initiated by our expedition at the adjacent part to the eastern wall of the church in 2014 revealed the continuation of the corridor with an eastern portal with pavement (Fig. 17) and 6 stairs going-down. (Fig. 18). So after these excavations we currently have an original plan of the sanctuary (Fig. 19). One of the major results of these excavations was the discovery of a basement crossing over the walls at a depth of 3 meters from the current surface, which made it possible to assert that the sepulchre was partly in the underground, and partly on the ground. The fragments of more than one hundred early medieval tile found during the excavations testify that the roof of the structure was tiled.

The third such type of sepulchre (with only eastern entrance) was uncovered by our expedition in 2016. That is a sepulchre of Saint Stephanos in the historical settlement of Vachar, on the right bank of Khachenaget river, not far from Gandzasar monastery (Fig. 20). ${ }^{12}$ One of its peculiarities was that it had a special section for relics constructed inside, in parallel with western wall. Thus, if Tigranakert's sepulchre is directly enclosed under the church's main altar, the sepulchre of Saint Grigoris is a combination of the underground and upper volumes. The Saint Stephanos sepulchre, initially was a standalone structure, and only in the 13 th century a second stair chapel was added.

Such diversity suggests that architects and builders were essentially trying to find more suitable forms of relationships with the structure holding the relics and ritual area, which can also speak about the impending chronology of such structures. The date of Saint Grigoris sepulchre seems to have no doubts at the end of the 5th century. Besides the clarified historical context, ${ }^{13}$ the sculptures can also be dated to the 5 th-6th centuries AD. ${ }^{14}$ As we have seen the sepulchre of Tigranakert was preceded by a small church, which preceded the large church. Recently, we have also received data on the carbon analysis of two burial bones at the western side of the small church: sarcophagus $-420-565$ years, stone cist-

12 See for more details Petrosyan 2019, 11-30.

13 Kałankatuac'i 1983, 83.

14 Hasratyan 1992, 19-24. 
566-655. ${ }^{15}$ At the same time, it is obvious that the burials were made when the church was already built, as they immediately touched its western walls. Particularly important is the data of the first analysis, according to which the first sarcophagus burial was performed after 420, but not later than 565. So the date of Tigranakert's sepulchre in the second half of the 5th century and at the beginning of the 6th century leaves no doubt. The same date could be confirmed by the constructional compositions of small and large churches of Tigranakert and by reliefs of the large church. ${ }^{16}$ The Armenian inscription on the clay disk found in the large basilica can be added as another artifact, this will be covered shortly afterwards.

\section{The Religious Reforms of Vachagan the Pious and the Jerusalemite Legend of Origin of Albanian Church}

So far, we can speak about three sepulchres, the specific aspect of which is the eastern entrance. ${ }^{17}$ Unfortunately, sepulchres with eastern entrances are unknown to us in the Middle East. There are no such scalable solutions to the well-known sepulchres-chapels known from other parts of Armenia (Aghtsk, Hripsime, Gayane, Talin, Oshakan, Nakhchavan and others). The only sepulchre, which has an eastern entrance, is the Lord's tomb in Jerusalem. ${ }^{18}$ According to our preliminary hypothesis, we are dealing with a religious reform, which tried to give the Albanian Church a special religious and ritual identity (differing from the Armenian Church) and essentially have political reasons.

In this regard, it is necessary to pay a special attention to the reforms of Vachagan the Pious in the last quarter of the 5th century or at the beginning of the 6th century, the perceptions of Albania as an eastern country and Yeghisha's legend.

The reforms of Vachagan included the new hierarchy of Albanian Church saints (Zacharia, Pantaleon, Grigoris, Grigori, Hripsime, Gayane) via < discovering $>$ their relics and constructing chapels and reliquaries for these relics (Saint Grigoris - in Amaras, Saint Pandaleon — in Diutakan, Saint Yeghisha — in Jrvshtik). In addition, the old church-

15 For these analysis, I am grateful to anthropologist Paul Bailey, armenologists Patrick Donabédian and Anna Leyloyan for their professional, friendly and financial support.

16 Petrosyan 2012, 172-174.

17 Let us note that the eastern entrance did not at all mean ignoring the dominant eastern-western ideological-ritual direction of Christianity. This is evidenced by the spatial resolution of the Saint Grigoris and Tigranakert's sepulchres, Tigranakerts sepulchre niches and small church direction, and even the westeast direction with an eastern altar of second floor chapel of Saint Stepanos sepulchre. East entrance was also attributed to an early church (4th-5th centuries?) uncovered in archaeological site Mingechaur on the river of Kur. Since there is no access to the three preserved walls of the structure and the eastern absorption has not been preserved, Azerbaijani archeologist R. Vahidov concluded that the entrance was probably from the east (Vahidov 1961, 95-97). R. Geushev supposed that in this case the altar was in the center of the building, and the entrance to the east (Gejušev 1964, 83). It is difficult to understand, how we can define a three walls structure without altar and entrance as a church. Excavations in Tigranakert and Gyavurkala (an Early Christian settlement in vicinity of Tigranakert), where none of the three churches lack access to eastern part and have eastern altars, seems to question such assumptions.

18 Wilkinson 1978, 6-13. 
es get a new impetus for worship thanks to these relics. ${ }^{19}$ Second, it was the council of Aghuen which adopted a new regulations for the Albanian church and the society as a whole. ${ }^{20}$

In parallel with this the ideology of Albania as an eastern country (in a number of contexts as well as the mean which differs from Armenia), which is witnessed in Vachagan's story ${ }^{21}$ and later, was created to be directly related to Jerusalem as the center of the Christian world and to the sacred topos of salvation. The hagiography of the Apostle Eghisha, who came to Albania from Jerusalem circumventing Armenia, fully corresponds with this line of thought and is an attempt to attest to the Jerusalemite origin of Albanian church. ${ }^{22}$

Thus, we have the sepulchre structures adapted to the direction of the Lord's tomb at the border of the 5th-6th centuries, the country's eastern ideology, the legend of the origins of Albanian church from Jerusalem. And we have a powerful ruler who has tried to convey an independent status to his church by means of religious reforms.

In his early exams Alexan Hakobyan considered the Vachagan history (including the "Aghuen's rules") as a "planned legend" created in the mid-6th century and thus questioned the historicity of the king himself. Our archaeological findings and historical data seem to indicate that these approaches and ideas have been formed politically via a real king and real reforms. ${ }^{23}$ In our opinion, it is the mighty king who would try to give to his church appropriate autonomy suitable to his kingdom (at that time, when Armenia lost its kingdom, became a Sasanid province and lost its north-eastern provinces Artskah nad Utik), a process that could be further clarified and finalized in the following centuries. Vachagan with his reforms, alongside Christian-Armenian traditions, was trying to shape its own traditions (Eastern country, Jerusalemite Apostol, “own” saints). And one of materialized expressions of this is the eastern entrance in the sepulchres.

Returning to the question of terminology for these constructions, it seems more suitable that name reliquary be used instead of the sepulchre. Because in all of these cases we have no evidence about burials but only stories about discoveries, gathering and putting the relics of saints in the buildings created for this specific purpose.

From this point of view, it is also remarkable that Vachagan erected the stella to the place of the martyrdom of Eghisha ${ }^{24}$ and transferred the relics of the saint to the Jrvshtik monastery of Artsakh (renamed the monastery to Eghisha Apostle). ${ }^{25}$ It should be noted

19 Kałankatuac'i 1983, 56-88.

20 Kałankatuac'i 1983, 89-94.

21 Ibid.

22 Kałankatuac'i 1983, 10-11.

23 In his latest works A. Hakobyan relates the "Novel of Vachagan" to the very beginning of the 6th century (cf. Hakobyan, not dated).

24 As we have noted, the remnants of such a monument were unearthed also in Tigranakert, in the courtyard between two churches.

25 Kałankatuac'i 1983, 12. The History of Movsēs Kałankatuac'i considers the main area of activity of Yeghisha the left bank of Kur river. It corresponds to the oldest tradition, up to the 19th century. Vachagan probably tried to shift some of the traditions of that time to the right bank of Kur, to new adjacent to his kingdom Armenian provinces Artsakh and Utik, which probably had more close ties with Armenian apostolic church. And two new monasteries after the name of Eghisha were established: near Amaras and in the Great Kvenq, to rename the last from the Jrvshtk to Egisha monastery. According to tradition, Vachagan was buried 
that according to same sources, the chapel of Grigoris was built directly by the order of Vachagan. ${ }^{26}$

\section{Some Evidence from Tigranakert}

In 2008, inside the territory of the large church, a small ceramic disk (diameter 7.5-7.8, thickness 0.5-1.0) was discovered (Fig. 21, 22). A circle and an equally winged cross on one side of the disk were engraved. The reverse had a portrait of a man wearing a fur hat, with a beard and moustache was carved. The disk had a hole making it possible to attach it to a box or scroll. So probably it was supposed to serve as a seal. There are Armenian

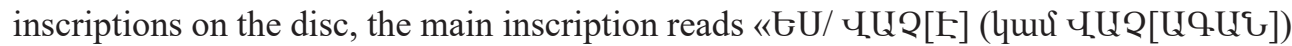

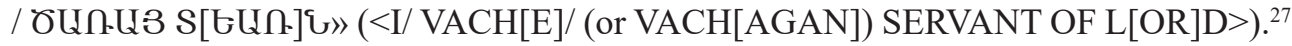

Examination of the disk, the caption and the Armenian fonts can be attributed to the 5th-7th centuries. The name of Vache or Vachagan was attributed to several people at that time. Vachagan the Pious is the most distinguished among them.

This finding of Tigranakert is actually one of the oldest Armenian records found in the territory of Artsakh, and the best argument for the early Christian-Armenian image of the city.

Noteworthy is a glass bottle in the shape of amphoriskos found in excavations at the same church (Fig. 23). The story of the of Saint Grigoris' relics is specifically relevant and important since it talks about two glass bottles in which the blood of the sacred Zacharias and Pandaleon was kept. ${ }^{28}$ Our amphoriskos appearance, made of dark blue glass, dates back to the 5th-7th centuries and is not less likely to have served similar purposes.

The folk tradition, which has reached us in the 19th century, connects Vachagan the Pious with the church of Vankasar. "... the king of Albania Vachagan came to Shahbulagh in his last years. He built a monastery on the top of the mountain, where he rested in seclusion." 29

\section{Christianization of Landscape as a Future Research Goal}

The archaeological investigations of Tigranakert have revealed four Early Christian compelxes in the city and its surrondings: the Early Christian square in the Central district, the church of 7th century on the top of Vankasar mountain, the Early Christian cave sanctuaries on the bank of Khachenaget river and a reliquary unearthed on the top of Tsitssar in 2019 (Fig. 24) and dated to the same period. So we can see the real recultur-

in this last monstery, where currently a 13th century mausoleum, and the 11th century tombstone and the khachkar are preserved.

26 Kałankatuac'i 1983, 82-83.

27 Petrosyan, Zhamkocyan 2009: 166-176.

28 Kaghankatvatsi: 81 .

29 Hayk'uni 2010, 39. 
alisation of the landscape in the Early Christian period (Fig. 25). It is curious to clarify how this organisation of landscape of Tigranakert can be connected with the reforms of Vachagan the Pious and Jerusalemian landscape and Christian sacred topography. This is a question which we will try to study via the next stage of excavations and research.

\section{BIBLIOGRAPHY}

\section{Primary Sources}

Barkhudareanc', M. (1895), Artsakh, Baku.

Movsēs Kałankatuac'i, Patmut 'iwn Atuanic 'Ašxarhi [History of the Country of the Albanians], Erevan. Sebēos (1979), Patmut' 'iwn [History], ed. G.V. Abgaryan, Erevan.

\section{Literature}

Eremyan, S. (1952), Atlas "Hay žolovrdi patmut 'iwn" grk 'i mas 1-i [Atlas of the First Part of the Book "History of the Armenian People"], Erevan.

Gejušev, R. (1964), Christianstvo v Kavkavskoj Albanii [Christianity in the Caucasian Albania], Baku.

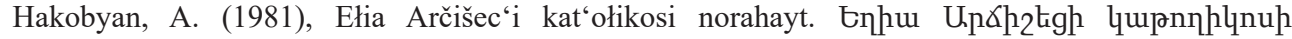
inpuhuuju pnınґp. The Newly Found Letter of the Kat'olikos Ełia Arčišec'i, Patma-banasirakan handes 4: 140-152.

Hakobyan A. (1987), Albanija-Aluank v greko-latinskih i drevnearmjanskih istočnikah [Albania-Aluank in the Greek-Latin and Ancient Armenian Sources], Erevan.

Hakobyan, A. (s.d.), The Creation of the Image "Pious" of Vachagan II, the Albanian King in the "Novel of Vachagan" (Beginning of the 6th Century), handwriting.

Hasratyan, M. (1992), Haykakan čartarapetut 'yan Arc 'axi dproc's [The Artsakh's School of Armenian Architecture], Erevan.

Hayk'uni, E. G. (2010), Ulegnac'akan aknarkner [Travel Guides] (written in 1885), Erevan.

Petrosyan, H. (1988), Garnin 9-14 darerum [Garni in the 9th-14th Centuries], Erevan.

Petrosyan, H. (2012), Similarities between the Early Christian Armenian Monuments and Irish High Crosses in the Light of New Discoveries, in: Ireland and Armenia: Studies in Language, History and Narrative, Washington, D.C.: 169-180.

Petrosyan, H. (2019), Vačarii surb Step'anos vank'i hnagitakan hetazodut'yan himnakan ardyunk'nerə ew norahayt arjanagrut' iwnnerə [The Main Results of the Archeological Research in the Monastery of Saint Stephanos in Vačar and the Newly Found Inscriptions], in: Sedrak Barxudaryan-120. Gitakan hodvacneri žołovacu [Sedrak Barxudaryan-120. Collection of Scientific Articles], Erevan: $11-30$.

Petrosyan, H., Kirakosyan, L. (2016), Rannexristianskij kul'tovo-peščernyj kompleks Arcakskogo Tigranakerta [The Early Christian Cave-Cultic Complex of Tigranakert in Artsakh], in: Peščery kak ob'ekty istorii i kul'tury: materialy meždunarodnogo naučnogo foruma [Caves as Objects of History and Culture: Materials of a Scientific International Forum], Voronež: 165-170.

Petrosyan, H., Žamkoč‘yan, A. (2009), Hayeren arjanagrut'yunnerov skavarak Arc'axi TIgranakertic‘ [A Disk with Armenian Inscriptions from Tigranakert in Artsakh], Patma-banasirakan handes 1: $166-176$.

Traina, G. (2015), Roman Representations of Caucasian Albania, in: A. Alikberov, M. Gadjiev (eds.), Albania Caucasica, vol. 1, Moskva: 42-46.

Vahidov, R. M. (1961), Mingačevir III-VIII asrlordə [Mingehaur in the 3rd-8th Centuries], Baku.

Wilkinson, J. (1978), The Church of the Holy Sepulchre, Archaeology 31(4): 6-13. 


\section{Illustrations ${ }^{30}$}

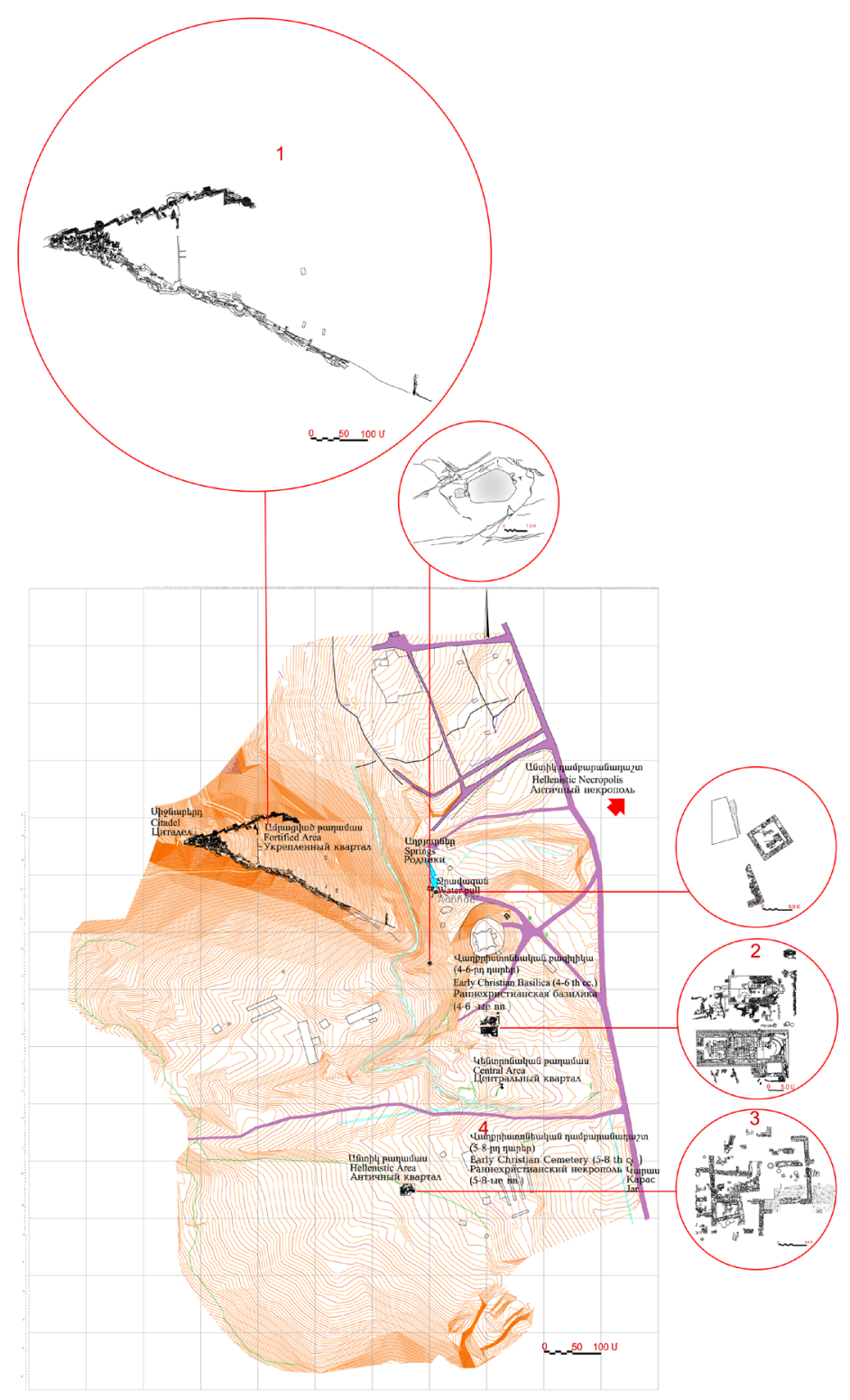

Fig. 1. Layout of Tigranakert with indications of the excavated areas, 2018

${ }^{30}$ All illustrations are a courtesy of the Artsakh archaeological expedition of the Institute of Archaeology and Ethnography, NAS RA. 


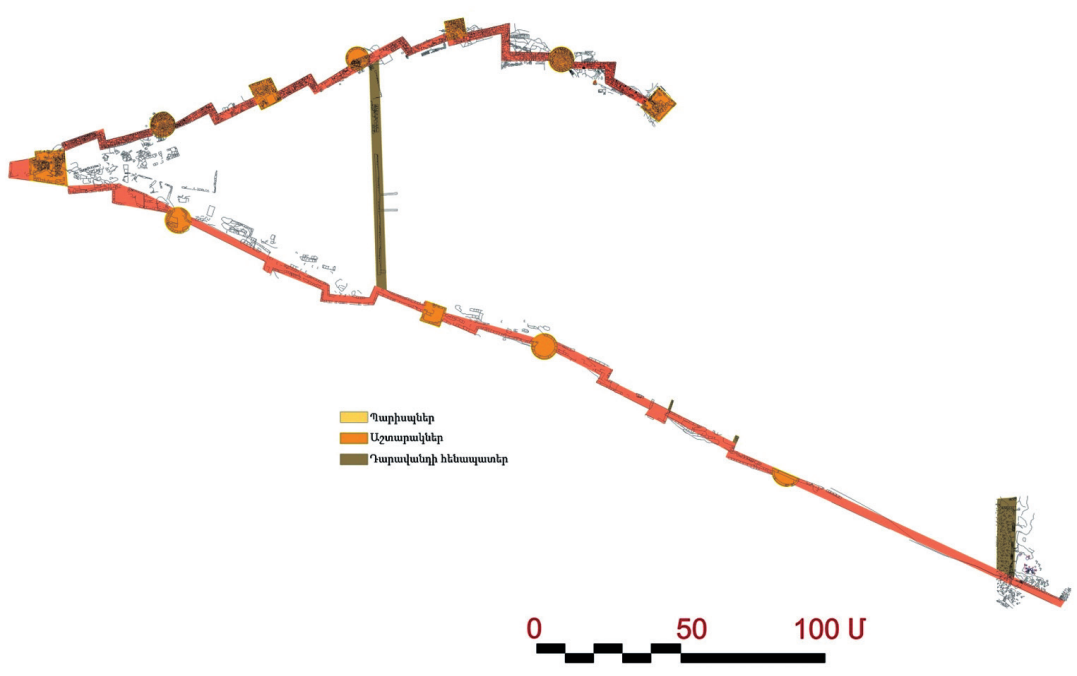

Fig. 2. Layout of the fortified district, 2018

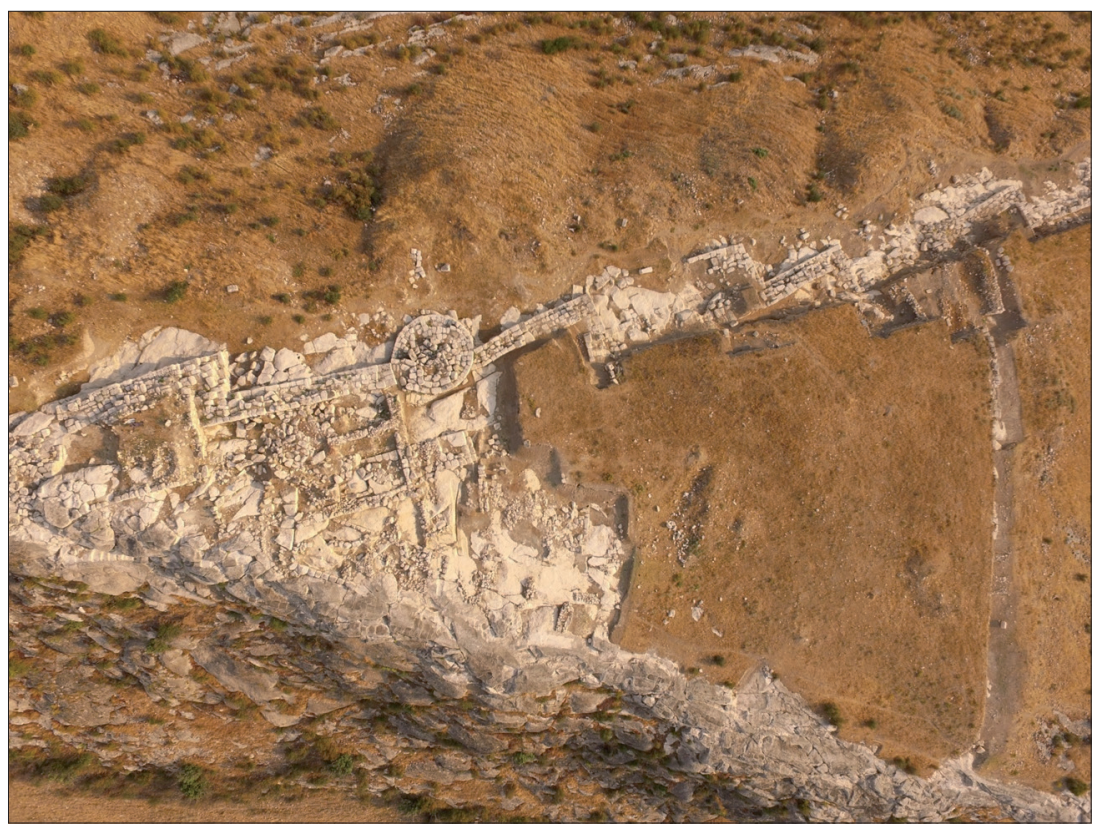

Fig. 3. Aerial view of the citadel of the fortified district, 2017 


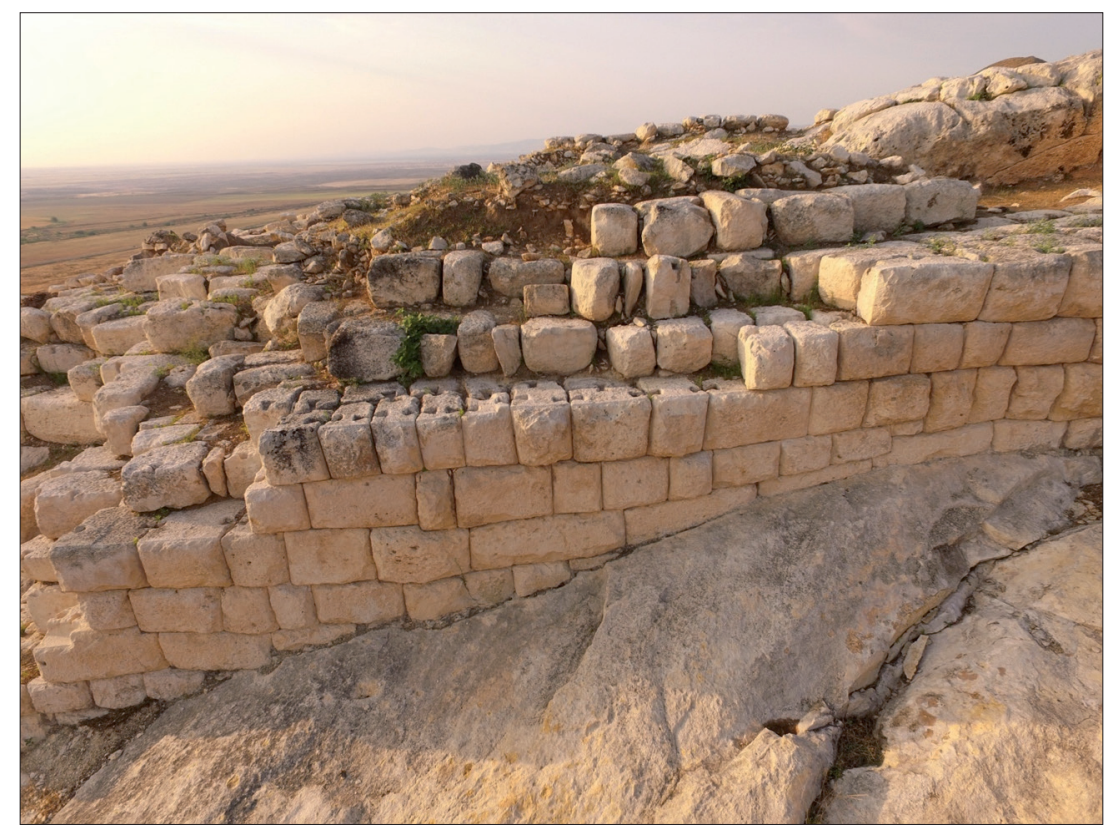

Fig. 4. The upper part of the northern fortification wall, 2009

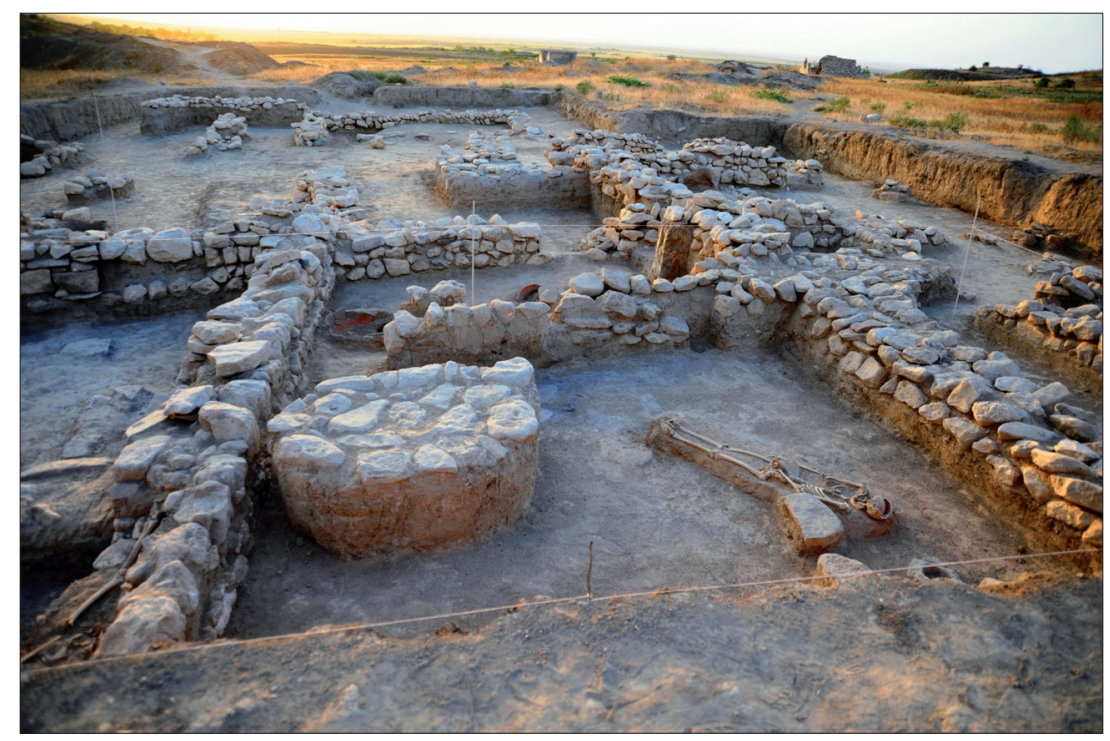

Fig. 5. Late Hellenistic district, 2014 


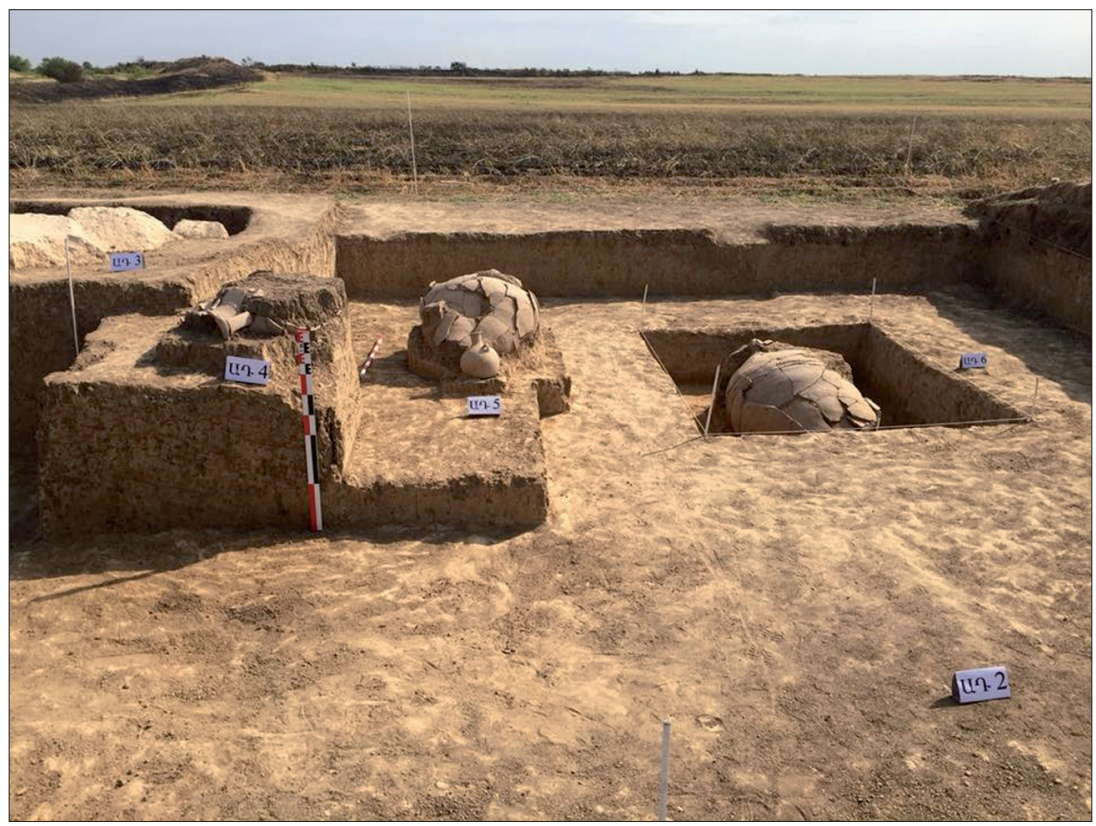

Fig. 6. Late Hellenistic cemetery, 2018

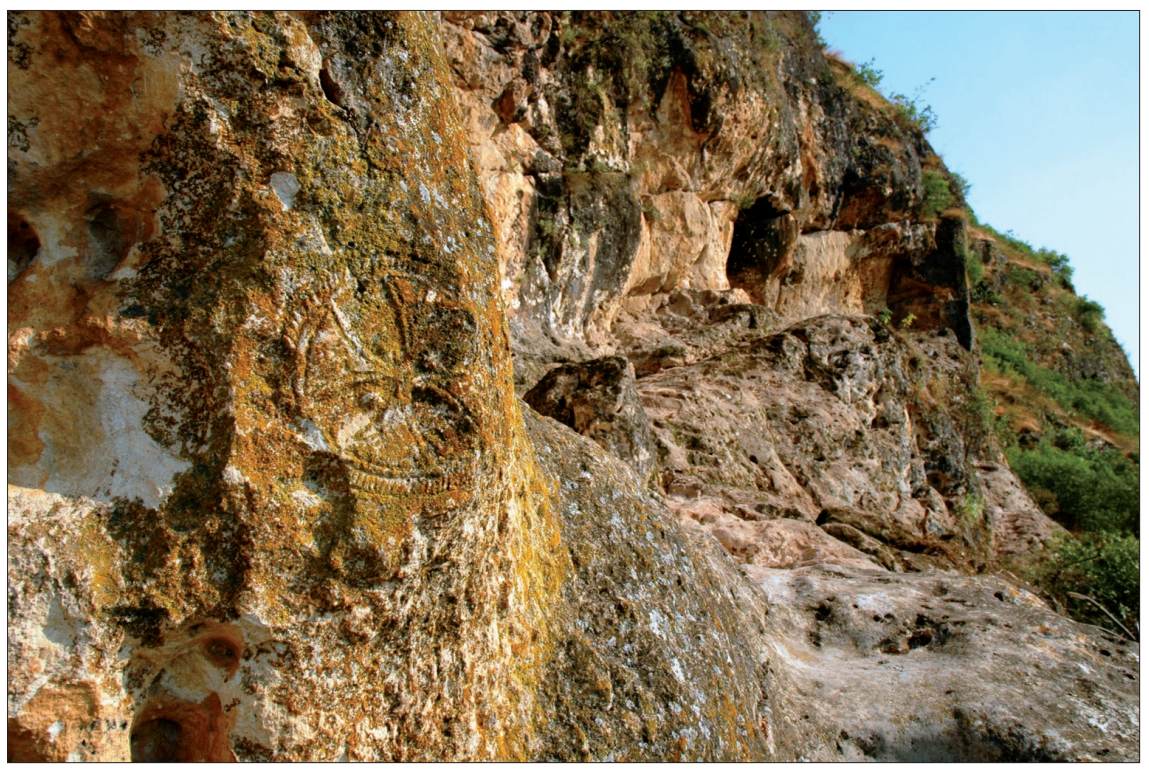

Fig. 7. Early Christian rock complex, the stairs 


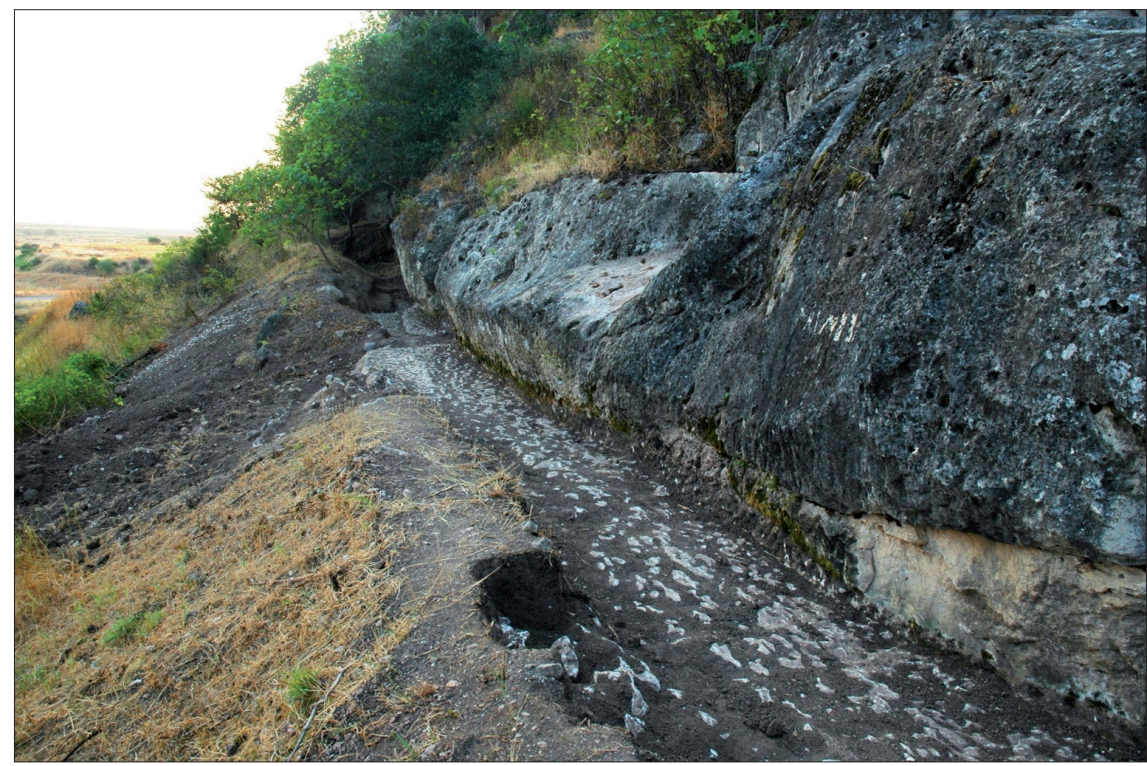

Fig. 8. Water canal, excavated rocky part, 2006

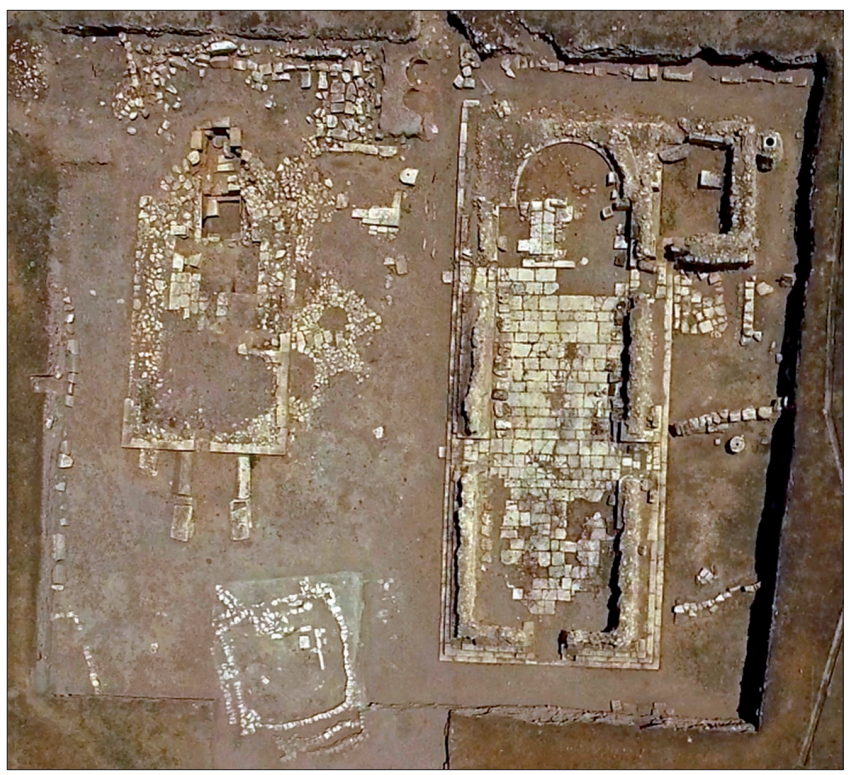

Fig. 9. Early Christian square, general view, 2017 


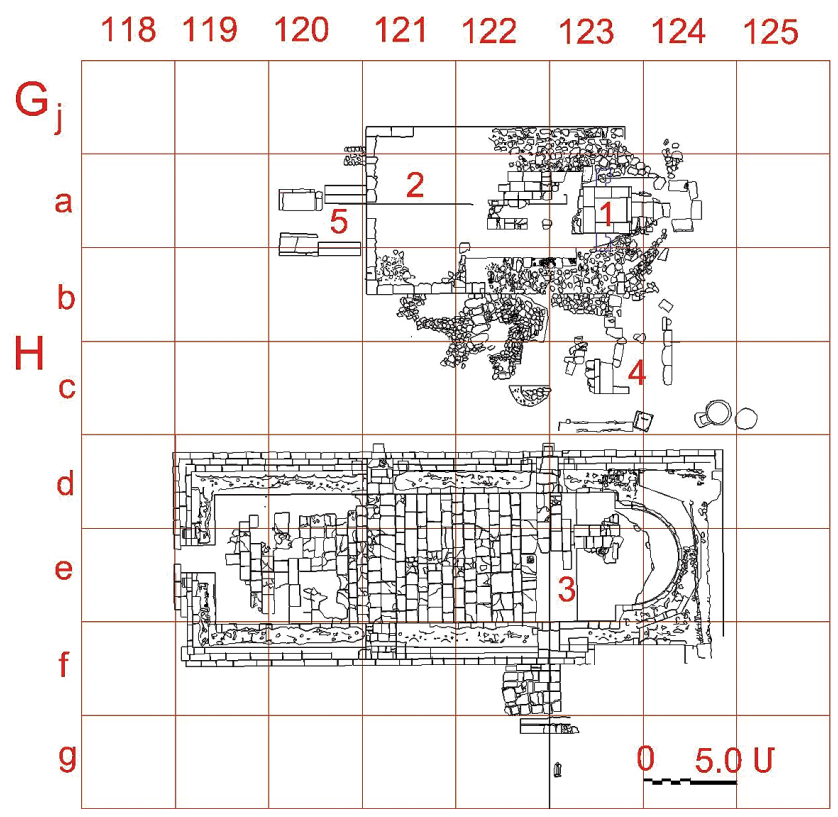

Fig. 10. Plans of Early Christian structures: 1. Sepulchre, 2. Small church, 3. Large church, 4. Monument, 5. Graveyard

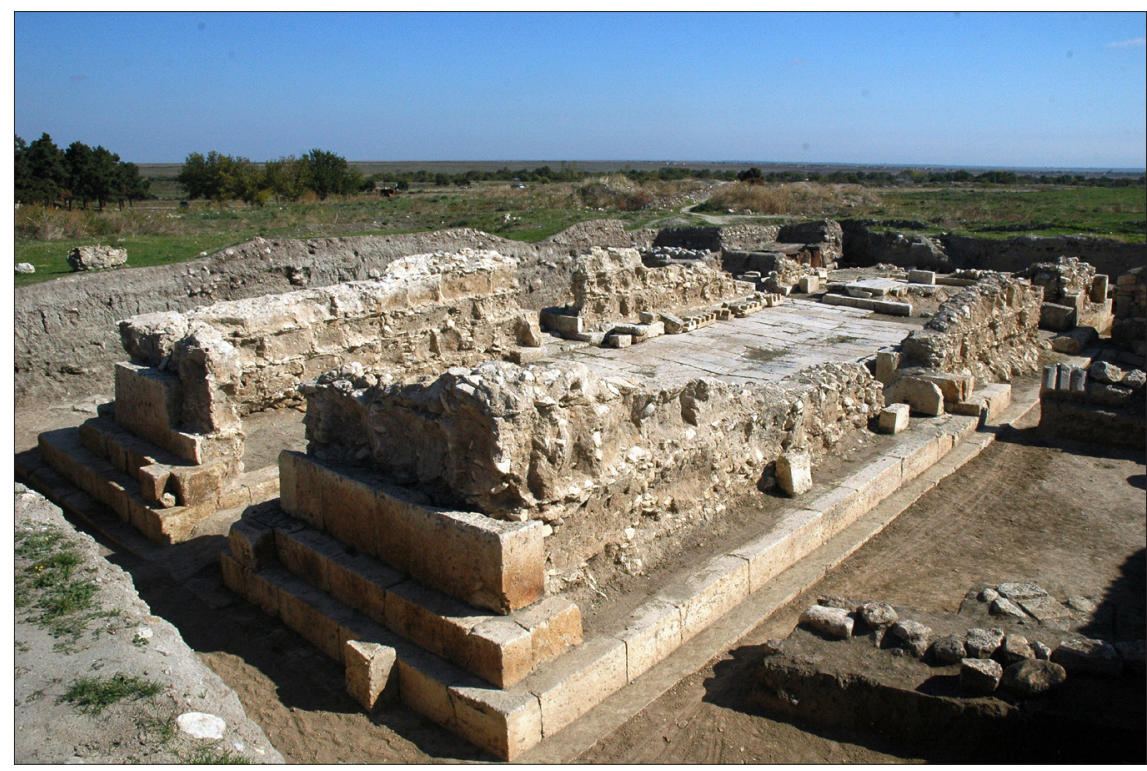

Fig. 11. The large basilica church, the 5th-6th centuries, general view from the south-west, 2009 


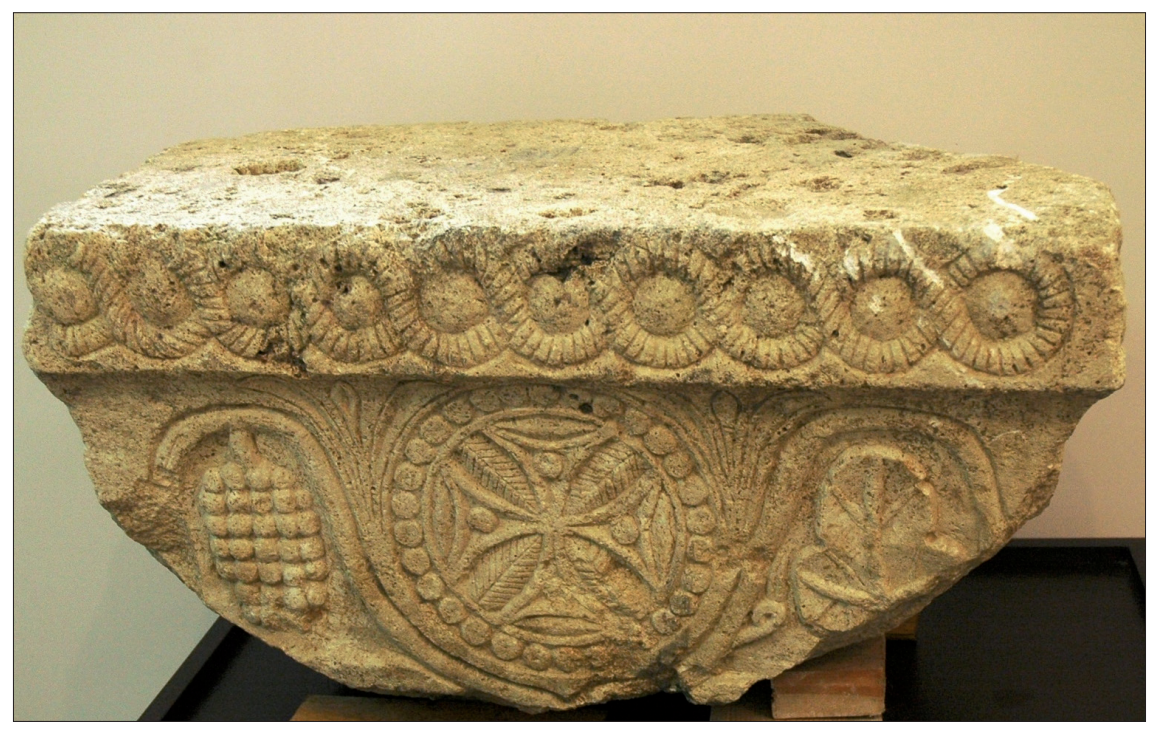

Fig. 12. A capital of the large basilica church, the cross in the garden environment

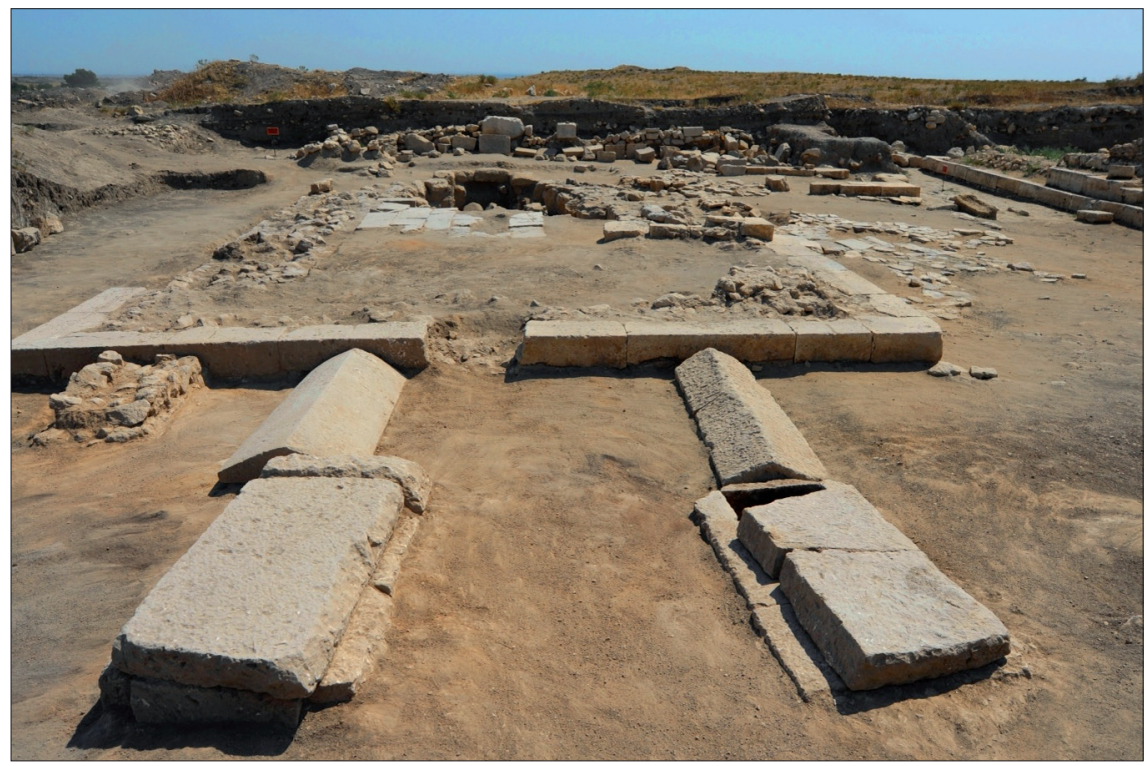

Fig. 13. Small basilica church and the graveyard, 2014 


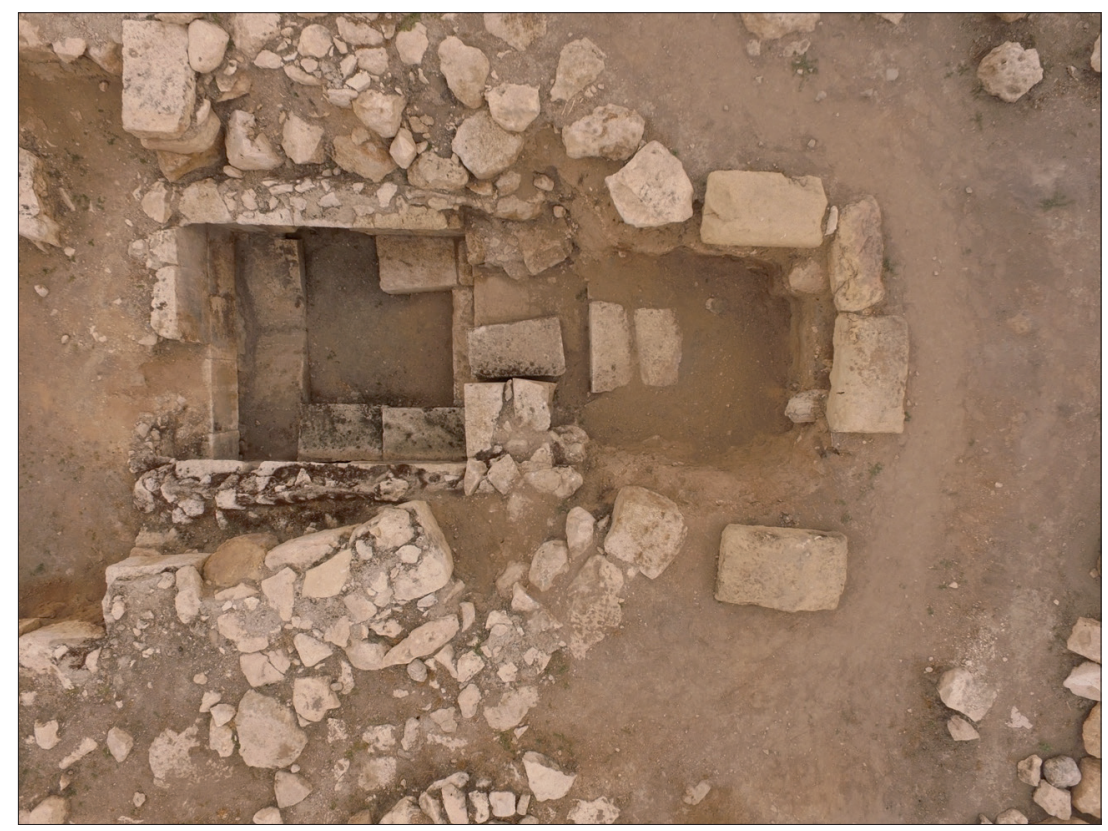

Fig. 14. Arial view on the Early Christian sepulchre, 2017

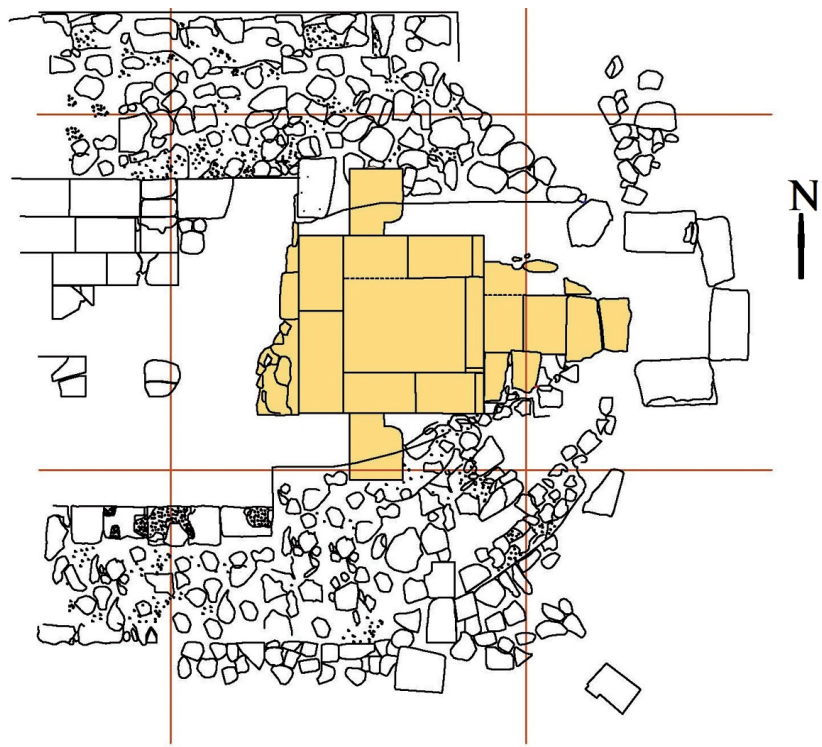

Fig. 15. Plan of the sepulchre 


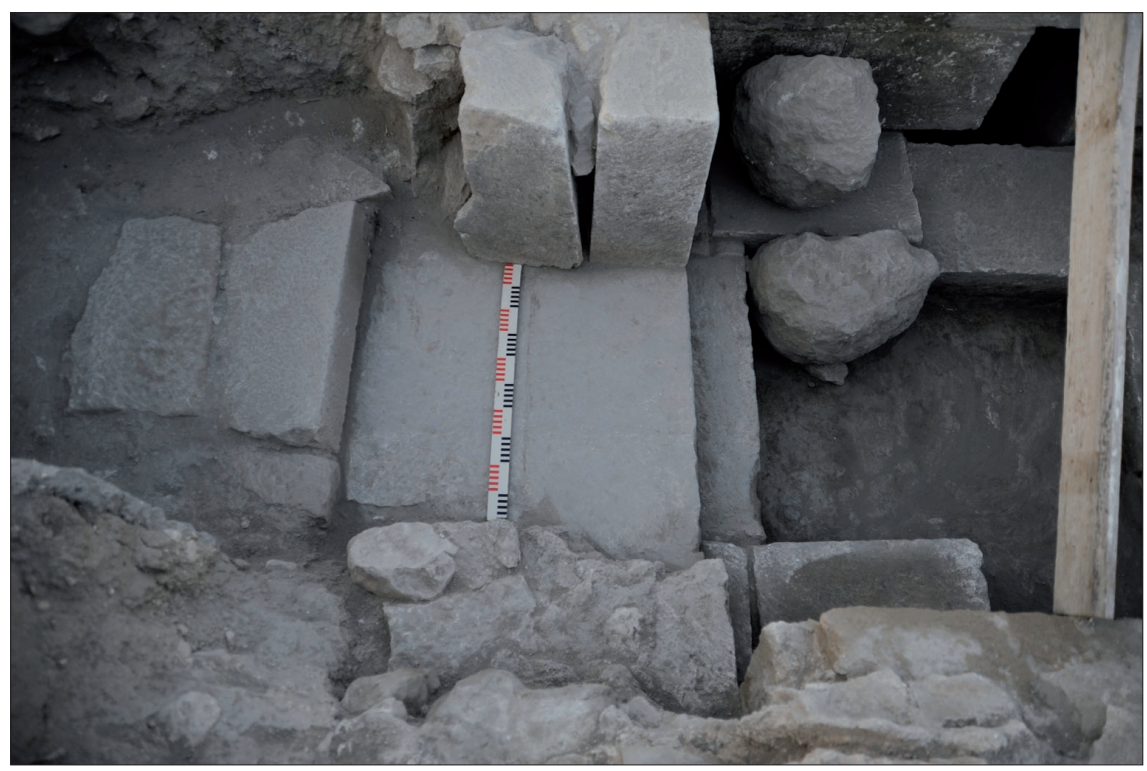

Fig. 16. Eastern entrance of Tigranakert's sepulchre

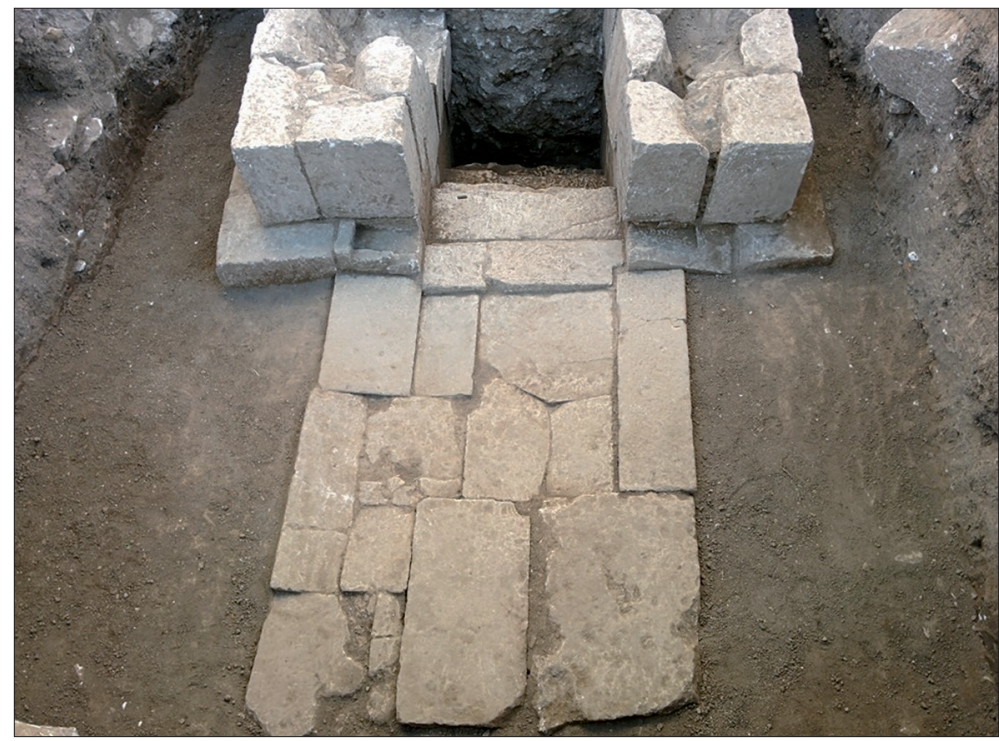

Fig. 17. The eastern entry of the St. Grigoris after the excavations, 2014 


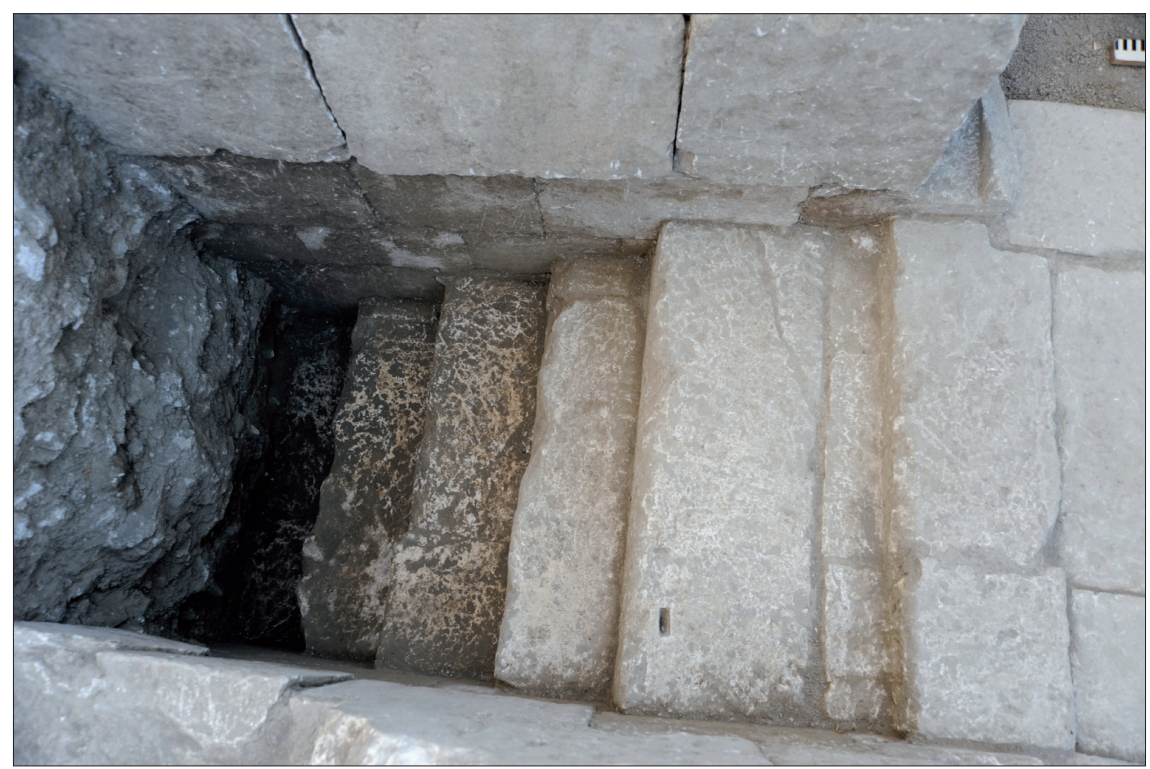

Fig. 18. Stairs of the entrans of St. Grigoris, 2014
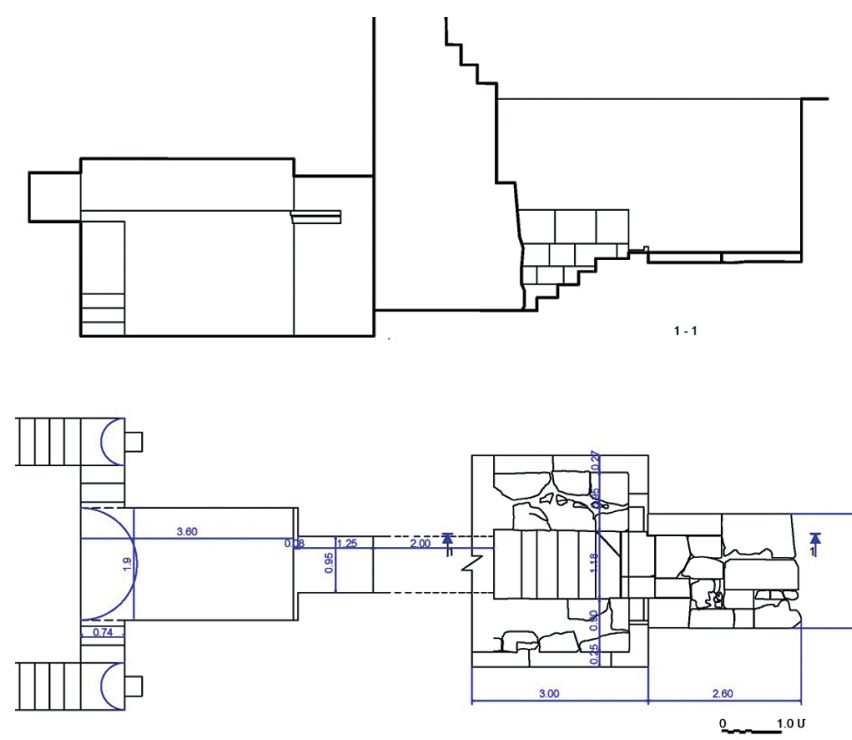

Fig. 19. Plan of St. Grigoris after the excavations 


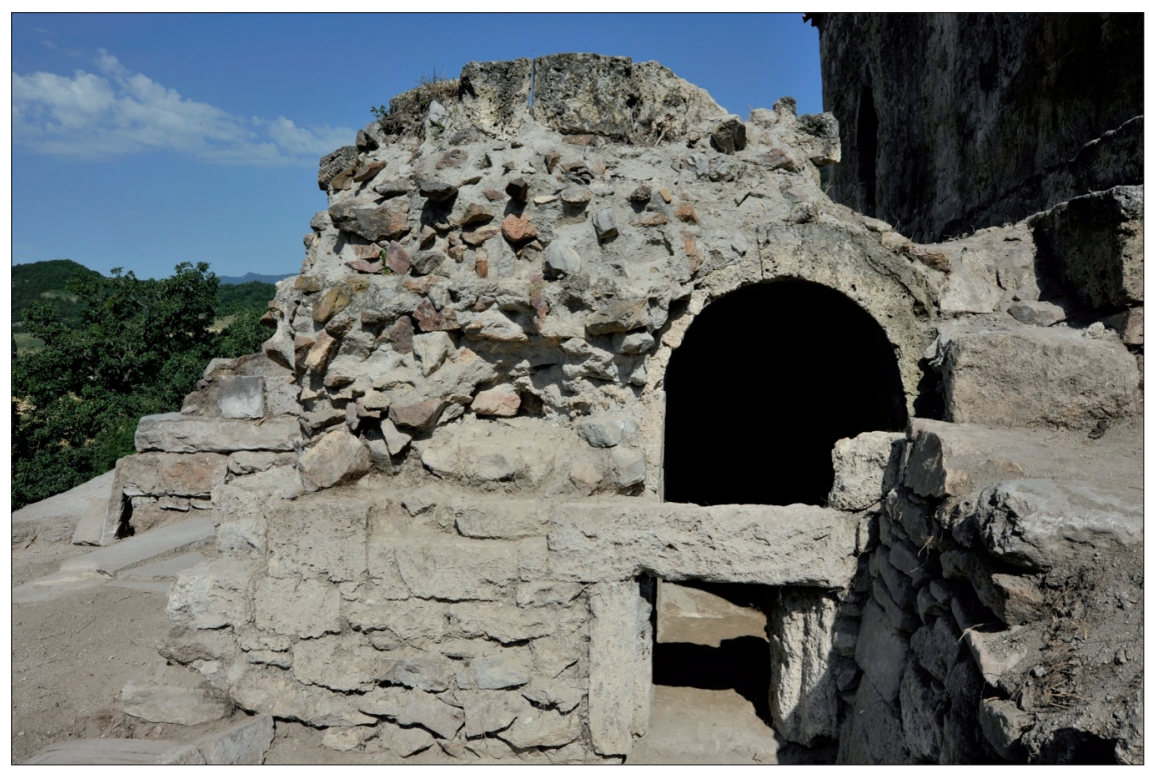

Fig. 20. The eastern entrance of St. Stephanos sepulchre in Vachar, 2017

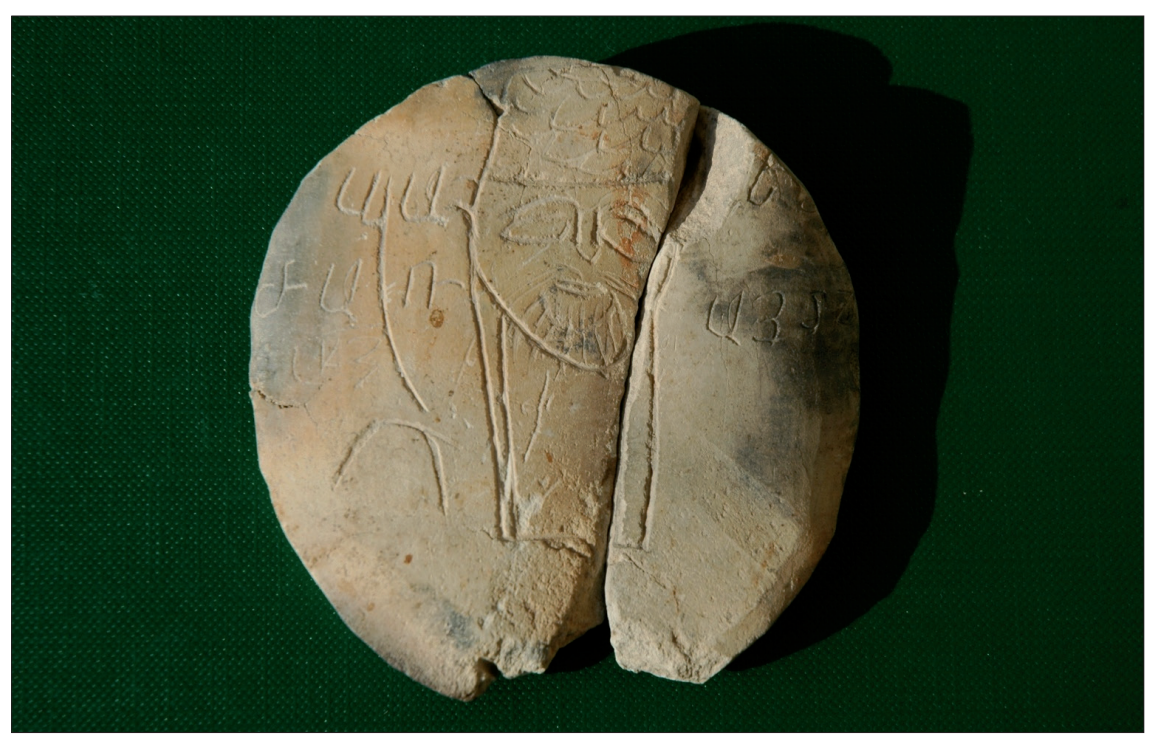

Fig. 21. A clay disc with Armenian inscriptions from the excavations of the Large Church, the front side 

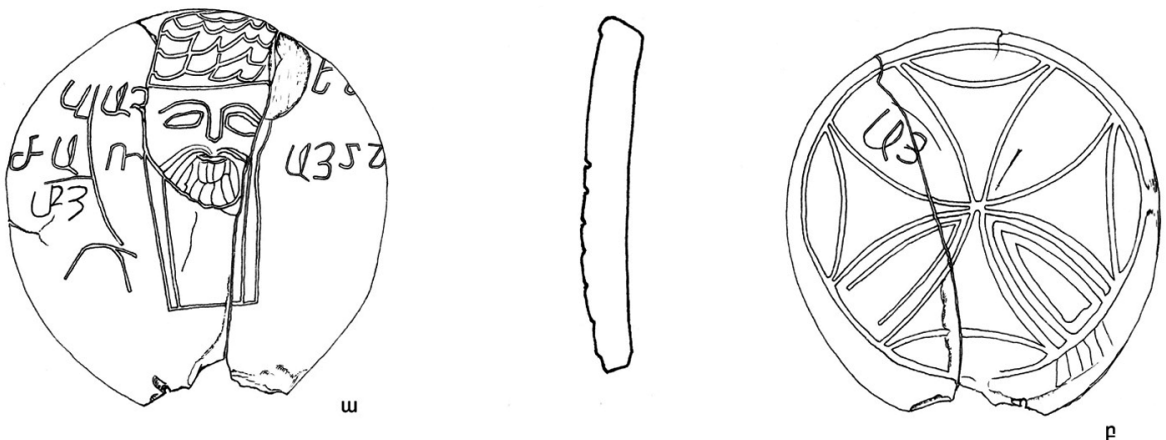

01 uर

Fig. 22. A clay disc with Armenian inscriptions from the excavations of the Large Church, the front and back sides, drowing

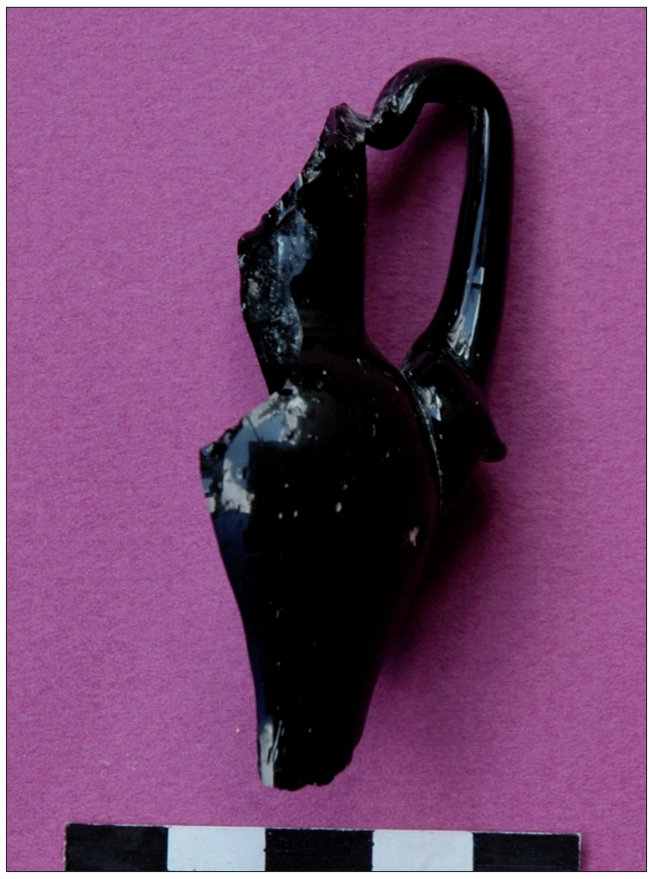

Fig. 23. Glass bottle from the excavations of the large church 


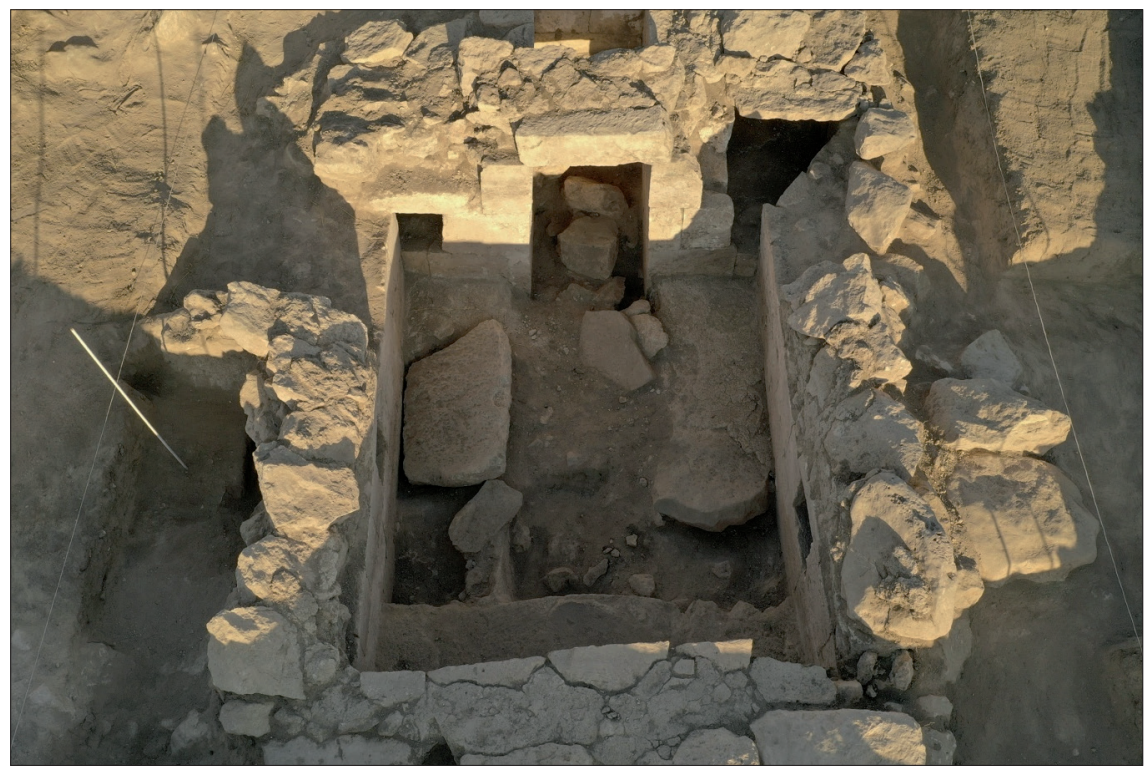

Fig. 24. The sepulchre on the Tsitsar Mountain, 2019

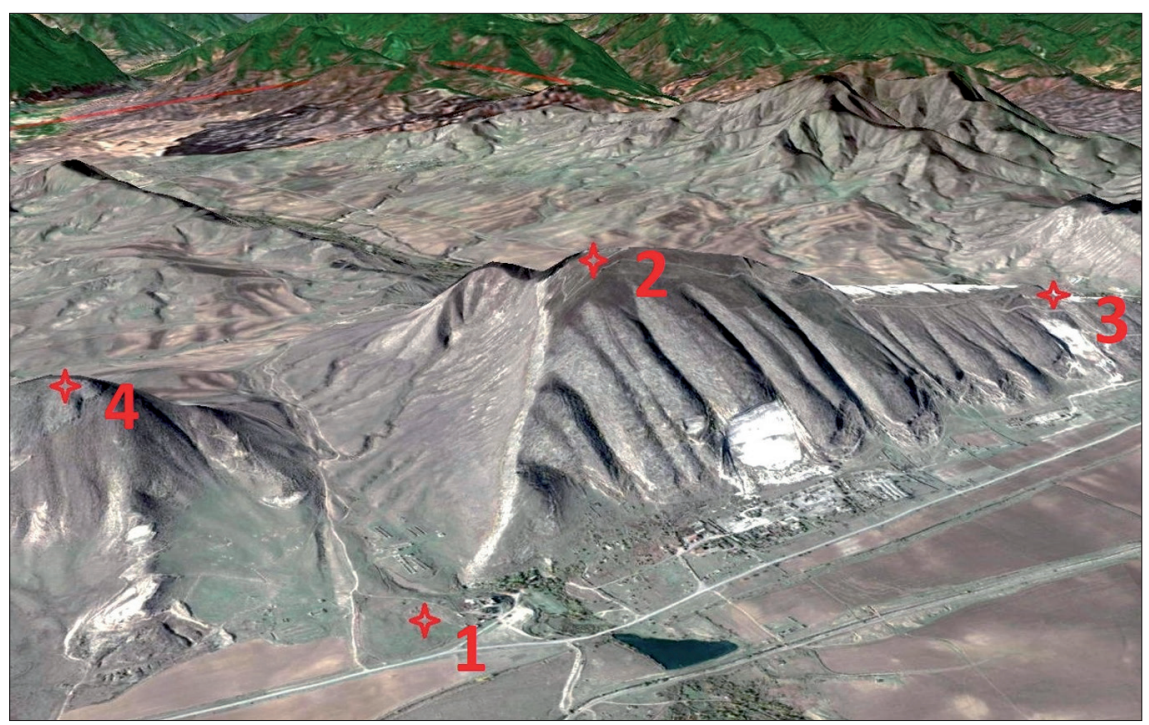

Fig. 25. The Landscape of the Early Christian Tigranakert. 1. The Early Christian square, 2. Vakasar's church, 3. Cave sanctuaries, 4. Sepulchre on Mount Tsitsar 